Louisiana State University

LSU Digital Commons

Faculty Publications

Department of Biological Sciences

$1-1-2007$

\title{
The African lungfish (Protopterus dolloi): lonoregulation and osmoregulation in a fish out of water
}

\author{
Michael P. Wilkie \\ McMaster University \\ Tammie P. Morgan \\ McMaster University \\ Fernando Galvez \\ McMaster University \\ Richard W. Smith \\ McMaster University \\ Makiko Kajimura \\ McMaster University
}

See next page for additional authors

Follow this and additional works at: https://digitalcommons.Isu.edu/biosci_pubs

\section{Recommended Citation}

Wilkie, M., Morgan, T., Galvez, F., Smith, R., Kajimura, M., Ip, Y., \& Wood, C. (2007). The African lungfish (Protopterus dolloi): Ionoregulation and osmoregulation in a fish out of water. Physiological and Biochemical Zoology, 80 (1), 99-112. https://doi.org/10.1086/508837

This Article is brought to you for free and open access by the Department of Biological Sciences at LSU Digital Commons. It has been accepted for inclusion in Faculty Publications by an authorized administrator of LSU Digital Commons. For more information, please contact ir@lsu.edu. 
Authors

Michael P. Wilkie, Tammie P. Morgan, Fernando Galvez, Richard W. Smith, Makiko Kajimura, Yuen K. Ip, and Chris M. Wood 
Wilfrid Laurier University

Scholars Commons @ Laurier

Biology Faculty Publications

Biology

2007

\title{
The African Lungfish (Protopterus dolloi): Ionoregulation and Osmoregulation in a Fish out of Water
}

\author{
Michael P. Wilkie \\ Wilfrid Laurier University, mwilkie@wlu.ca \\ Tammie P. Morgan \\ McMaster University \\ Fernando Galvez \\ Louisiana State University \\ Richard W. Smith \\ McMaster University \\ Makiko Kajimura \\ McMaster University
}

See next page for additional authors

Follow this and additional works at: https://scholars.wlu.ca/biol_faculty

\section{Recommended Citation}

Wilkie, Michael P.; Morgan, Tammie P.; Galvez, Fernando; Smith, Richard W.; Kajimura, Makiko; Ip, Yuen K.; and Wood, Chris M., "The African Lungfish (Protopterus dolloi): Ionoregulation and Osmoregulation in a Fish out of Water" (2007). Biology Faculty Publications. 45.

https://scholars.wlu.ca/biol_faculty/45

This Article is brought to you for free and open access by the Biology at Scholars Commons @ Laurier. It has been accepted for inclusion in Biology Faculty Publications by an authorized administrator of Scholars Commons @ Laurier. For more information, please contact scholarscommons@wlu.ca. 


\section{Authors}

Michael P. Wilkie, Tammie P. Morgan, Fernando Galvez, Richard W. Smith, Makiko Kajimura, Yuen K. Ip, and Chris M. Wood 


\section{The African Lungfish (Protopterus dolloi): Ionoregulation and Osmoregulation in a Fish out of Water}

\author{
Michael P. Wilkie ${ }^{1,2, *}$ \\ Tammie P. Morgan ${ }^{1}$ \\ Fernando Galvez ${ }^{1,3}$ \\ Richard W. Smith ${ }^{1}$ \\ Makiko Kajimura ${ }^{1}$ \\ Yuen K. Ip ${ }^{4}$ \\ Chris M. Wood ${ }^{1}$ \\ ${ }^{1}$ Department of Biology, McMaster University, Hamilton, \\ Ontario L8S 4K1, Canada; ${ }^{2}$ Department of Biology, Wilfrid \\ Laurier University, Waterloo, Ontario N2L 3C5, Canada; \\ ${ }^{3}$ Department of Biological Sciences, Louisiana State \\ University, Baton Rouge, Louisiana 70803-1715; ${ }^{4}$ Department \\ of Biological Science, National University of Singapore, Kent \\ Ridge, Singapore 117543, Republic of Singapore
}

Accepted 8/28/2006; Electronically Published 11/15/2006

\section{ABSTRACT}

Although urea production and metabolism in lungfish have been thoroughly studied, we have little knowledge of how internal osmotic and electrolyte balance are controlled during estivation or in water. We tested the hypothesis that, compared with the body surface of teleosts, the slender African lungfish (Protopterus dolloi) body surface was relatively impermeable to water, $\mathrm{Na}^{+}$, and $\mathrm{Cl}^{-}$due to its greatly reduced gills. Accordingly, we measured the tritiated water $\left({ }^{3} \mathrm{H}-\mathrm{H}_{2} \mathrm{O}\right)$ flux in $P$. dolloi in water and during air exposure. In water, ${ }^{3} \mathrm{H}-\mathrm{H}_{2} \mathrm{O}$ efflux was comparable with the lowest measurements reported in freshwater teleosts, with a rate constant $(K)$ of $17.6 \%$ body water $\mathrm{h}^{-1}$. Unidirectional ion fluxes, measured using ${ }^{22} \mathrm{Na}^{+}$and ${ }^{36} \mathrm{Cl}^{-}$, indicated that $\mathrm{Na}^{+}$and $\mathrm{Cl}^{-}$influx was more than $90 \%$ lower than values reported in most freshwater teleosts. During air exposure, a cocoon formed within $1 \mathrm{wk}$ that completely covered the dorsolateral body surface. However, there were no disturbances to blood osmotic or ion $\left(\mathrm{Na}^{+}, \mathrm{Cl}^{-}\right)$balance, despite seven- to eightfold increases in plasma urea after $20 \mathrm{wk}$. Up to 13-fold increases in muscle urea (on a dry-weight basis) were the likely explanation for the $56 \%$ increase in muscle water

\footnotetext{
*Corresponding author. Address for correspondence: Department of Biology, Wilfrid Laurier University, 75 University Avenue West, Waterloo, Ontario N2L 3C5, Canada; e-mail: mwilkie@wlu.ca.
}

Physiological and Biochemical Zoology 80(1):99-112 2007 (C) 2007 by The University of Chicago All rights reserved 1522-2152/2007/8001-6065\$1500 content observed after $20 \mathrm{wk}$ of air exposure. The possibility that muscle acted as a "water reservoir" during air exposure was supported by the $20 \%$ decline in body mass observed during subsequent reimmersion in water. This decline in body mass was equivalent to $28 \mathrm{~mL}$ water in a 100 -g animal and was very close to the calculated net water gain (approximately $32 \mathrm{~mL}$ ) observed during the 20 -wk period of air exposure. Tritiated water and unidirectional ion fluxes on air-exposed lungfish revealed that the majority of water and ion exchange was via the ventral body surface at rates that were initially similar to aquatic rates. The ${ }^{3} \mathrm{H}-\mathrm{H}_{2} \mathrm{O}$ flux declined over time but increased upon reimmersion. We conclude that the slender lungfish body surface, including the gills, has relatively low permeability to water and ions but that the ventral surface is an important site of osmoregulation and ionoregulation. We further propose that an amphibian-like combination of ventral skin water and ion permeability, plus internal urea accumulation during air exposure, allows $P$. dolloi to extract water from its surroundings and to store water in the muscle when the water supply becomes limited.

\section{Introduction}

The six species of lungfish (subclass: Sarcopterygii) belong to the families Ceratodontidae (Australian lungfish; Neoceratodus forsteri), Lepidosirenidae (South American lungfish; Lepidosiren paradoxa), and Protopteridae, which comprises the four species of African lungfish belonging to the genus Protopterus (P. aethiopicus, P. amphibius, P. annectens, P. dolloi; see Graham 1997 for review). The Protopteridae are distributed across tropical Africa, and these obligate air breathers have been subject to intense scrutiny by respiratory physiologists interested in the evolution and development of air breathing in vertebrates (e.g., Smith 1931; McMahon 1970; Johansen et al. 1976a; Laurent et al. 1978; Perry et al. 2005). The African lungfish are also renowned for their ability to enter a prolonged (up to 4 yr) state of torpor or estivation during periods of extreme drought (e.g., Smith 1931; Janssens 1964; DeLaney et al. 1974). With the onset of the dry season, some lungfish burrow into the mud and secrete a mucus cocoon that surrounds the body to reduce desiccation (see Fishman et al. 1986 for review). During both estivation and air exposure, nitrogenous wastes are also converted to and stored in the body as urea, rather than as the more toxic ammonia (Smith 1930, 1931; Janssens 1964; Jans- 
sens and Cohen 1968; DeLaney et al. 1974, 1977; Chew et al. 2003, 2004; Loong et al. 2005; Wood et al. 2005). Only $P$. annectens is reported to estivate in nature on a regular basis (Greenwood 1986), but all African lungfish have the ability to secrete a cocoon and to enter an estivation-like state when denied access to water in the laboratory. Although nitrogenous waste production and excretion during estivation have been studied extensively, less is known about how internal ion and osmotic balance is maintained in lungfish during periods of water shortage. The goal of this study was to determine how the slender lungfish P. dolloi controls internal osmotic and electrolyte balance while in water and during periods of limited water availability due to air exposure.

In most freshwater fish species, the gills are the major site of ion exchange (Perry 1997; Marshall 2002), but they are also the major route of water entry due to the large surface area generated by numerous filaments containing secondary lamellae (Evans 1979). The gills of lungfish, however, are greatly reduced and characterized by a lack of gill filaments and secondary lamellae on the anterior gill arches and relatively low numbers of these structures on the posterior arches (Laurent et al. 1978; Burggren and Johansen 1986). As a result, in juvenile and adult life stages, the gills play a relatively minor role in gas exchange, with most $\mathrm{O}_{2}(>80 \%)$ uptake occurring via the lungs (McMahon 1970; Johansen et al. 1976a; Perry et al. 2005). Based on these facts, a key objective of this study was to test the hypothesis that the gills and general body surface (skin) of P. dolloi were relatively impermeable to water, $\mathrm{Na}^{+}$, and $\mathrm{Cl}^{-}$ while the animals were submerged in water. We tested this hypothesis by measuring rates of exchangeable water turnover between $P$. dolloi and its environment by tracking the appearance of radioactive ${ }^{3} \mathrm{H}-\mathrm{H}_{2} \mathrm{O}$ in the water after its injection into the intraperitoneal (IP) cavity (Evans 1967; Potts et al. 1970). Unidirectional $\mathrm{Na}^{+}$and $\mathrm{Cl}^{-}$flux rates were also determined by measuring the changes in water radioactivity after the external addition of ${ }^{22} \mathrm{Na}^{+}$and ${ }^{36} \mathrm{Cl}^{-}$(Wood 1988; Wilkie et al. 1998) to determine basal rates of ion exchange across the body surface of P. dolloi.

All of the African lungfish are amphibious, and $P$. dolloi lives in marginal, swampy habitat (Greenwood 1986) where it could be subject to short periods of air exposure while stranded in puddles or during temporary aerial excursions. Under such circumstances, the gills would be inoperative due to the collapse of secondary lamellae and fusion of gill filaments on the posterior arches (Sturla et al. 2002). An ability to continue uptake of water and/or ions from the limited water remaining in their habitat by using other routes/mechanisms could therefore prolong lungfish survival by minimizing the severity of osmotic and ionic disturbances. To examine this possibility, we took advantage of the ability of $P$. dolloi to survive out of water for prolonged periods by entering an estivation-like state characterized by the secretion of a cocoon that envelops the animal's dorsolateral body surface while the ventral surface remains in contact with the moist substrate (Chew et al. 2003; Wood et al. 2005). Because humid conditions are essential for survival under such circumstances, we predicted that water and ion uptake would take place across the ventral body surface. To test this hypothesis, ${ }^{3} \mathrm{H}-\mathrm{H}_{2} \mathrm{O}$ and unidirectional $\mathrm{Na}^{+}$and $\mathrm{Cl}^{-}$ flux measurements were performed on acutely $(4-8 \mathrm{~h})$ and chronically ( 1 wk-6 mo) air-exposed lungfish that were suspended over a water bath that was in contact with only the ventral body surface. These studies were also accompanied by measurements of plasma nitrogen stores (ammonia, urea, trimethylamine oxide), osmolality and ion concentrations, and water and urea content of muscle to assess how effectively the lungfish defended osmotic and ionic status during prolonged air exposure.

\section{Material and Methods}

\section{Experimental Animals and Holding}

Adult slender African lungfish averaging $156 \mathrm{~g}$ in mass (range $=56-274 \mathrm{~g}$ ), originally captured in western Africa, were purchased from a tropical fish dealer in Singapore and then air-shipped to McMaster University, in Hamilton, Ontario, in plastic bags that were partially filled with water and had an overlying air phase that was saturated with oxygen. The lungfish were subsequently held individually in static $10-\mathrm{L}$ covered aquaria, containing approximately $2 \mathrm{~L}$ of warm $\left(25^{\circ}-28^{\circ} \mathrm{C}\right)$ water, and subject to a $12 \mathrm{~L}: 12 \mathrm{D}$ photoperiod. Because African lungfish are obligate air breathers, aeration of the water was not necessary, but the water was supplemented with Instant Ocean, resulting in $\left[\mathrm{Na}^{+}\right] \sim 2.0 \mathrm{mmol} \mathrm{L}{ }^{-1},\left[\mathrm{Cl}^{-}\right] \sim 1.8 \mathrm{mmol}$ $\mathrm{L}^{-1}$, and $\left[\mathrm{Ca}^{2+}\right] \sim 1.2 \mathrm{mmol} \mathrm{L}{ }^{-1} ; \mathrm{pH} \sim 7.8$; and hardness $\sim 170$ ppm, which minimized the incidence of fungal infections and overall stress. The lungfish were fed bloodworms (chironomid larvae) three times per week, but non-air-exposed lungfish (aquatic) were starved for 3-5 d before experiments to minimize possible artifacts that feeding might have introduced to ion or ${ }^{3} \mathrm{H}-\mathrm{H}_{2} \mathrm{O}$ measurements. This also permitted more meaningful comparisons between aquatic and air-exposed lungfish, which do not feed while estivating. All experimental and holding procedures used followed Canadian Council on Animal Care guidelines and were approved by the McMaster University Animal Care Committee.

\section{Experimental Protocol and Air Exposure}

Air exposure was achieved by completely draining each holding chamber $(25 \mathrm{~cm} \times 18.5 \mathrm{~cm})$ and then adding back $20 \mathrm{~mL}$ of water (same composition as above) to create a film of water on the bottom of each chamber. The animals were sprayed every sixth day with a fine mist of water to maintain high relative humidity throughout the air-exposure period ( $1 \mathrm{wk}-6$ mo). To minimize disturbance, air-exposed animals were held under constant darkness, but they were inspected twice per day, 
except on weekends (once per day). Under these conditions, it was noted that cocoon formation began within 1-2 d of initiating air exposure, and after approximately $1 \mathrm{wk}$, a clearly discernible cocoon could be seen covering the animal's dorsolateral body surface. Of the 45 lungfish that were exposed to air for $1 \mathrm{wk}$ or longer, 42 survived air exposure and reimmersion in water.

Experiment 1: Effects of Air Exposure on Osmotic, Ionic, and Nitrogenous Waste Balance. Lungfish were held under aquatic (control) or terrestrial (air exposure) conditions for 1, 4, or 20 wk. At the conclusion of each period, blood samples (50-500 $\mu \mathrm{L}$ ) were collected by caudal puncture using 26-gauge insulin syringes that were prerinsed with $\mathrm{Na}^{+}$-heparin $\left(1 \mathrm{mg} \mathrm{mL}^{-1}\right)$; the samples were subsequently centrifuged at $10,000 \mathrm{~g}$ for 3 min to separate the plasma from the corpuscular portion. Where sufficient blood was available $(>200 \mu \mathrm{L})$, hematocrit was also determined using $\mathrm{Na}^{+}$-heparinized capillary tubes centrifuged for $5 \mathrm{~min}$ at $6,000 \mathrm{~g}$. Plasma was transferred to $500-\mu \mathrm{L}$ centrifuge tubes, frozen in liquid $\mathrm{N}_{2}$, and stored at $-80^{\circ} \mathrm{C}$ until analyzed for plasma osmolality, ions $\left(\mathrm{Na}^{+}, \mathrm{Cl}^{-}\right)$, and nitrogenous compounds (ammonia, urea, and trimethylamine oxide [TMAO]). Muscle samples were also collected from the dorsolateral side of a subset of anesthetized animals that were terminally sampled, under aquatic conditions or after air exposure for 4 or $20 \mathrm{wk}$, for determination of muscle water and urea content.

To determine how the simultaneous stresses of starvation and air exposure affected body mass, lungfish were weighed at the beginning and end of 1, 4, or 20 wk of air exposure. Changes in body mass were also monitored in a subset of four animals during reimmersion after $20 \mathrm{wk}$ of air exposure to determine how the return to completely aquatic conditions affected net water balance. In these experiments, mass was determined at $0,1,2,4,6,8,10,12,24,48$, and $72 \mathrm{~h}$ of reimmersion.

Experiment 2: Effects of Air Exposure on ${ }^{3} \mathrm{H}-\mathrm{H}_{2} \mathrm{O}$ Flux across the Ventral Body Surface. To examine water flux, we measured ${ }^{3} \mathrm{H}-$ $\mathrm{H}_{2} \mathrm{O}$ movements across the lungfish body surface (gills, skin, and also renal routes) in water and in air (ventral body surface only) after IP injection of $0.75 \mathrm{mCi} \mathrm{kg}{ }^{-1}$ of ${ }^{3} \mathrm{H}-\mathrm{H}_{2} \mathrm{O}$ taken from a $0.5 \mu \mathrm{Ci}^{3} \mathrm{H}_{-} \mathrm{H}_{2} \mathrm{O} \mu \mathrm{L}^{-1}$ stock dissolved in physiological saline. Before injection, body weights were determined in aquaticphase animals by covering them with a moistened cloth to prevent damage to their delicate skin, blotting them dry, and then recording mass to the nearest $0.1 \mathrm{~g}$, using an analytical balance. The fish were then wrapped again with the moist cloth and positioned firmly on a large moistened sponge, and the ${ }^{3} \mathrm{H}-\mathrm{H}_{2} \mathrm{O}$ was injected. Care was taken to ensure that the ${ }^{3} \mathrm{H}-$ $\mathrm{H}_{2} \mathrm{O}$ solution did not leak out of the injection site. As an additional precaution, the ${ }^{3} \mathrm{H}-\mathrm{H}_{2} \mathrm{O}$-injected lungfish were left $1 \mathrm{~h}$ to allow the isotope to become equilibrated throughout the extracellular and intracellular spaces (Evans 1967). Air- exposed animals were injected in a similar manner, but damage to the cocoon was minimal because the site of injection (ventral body surface) lacked this covering. After injection, the aquatic or air-exposed lungfish were transferred to the appropriate experimental chamber for measurement of the ${ }^{3} \mathrm{H}-\mathrm{H}_{2} \mathrm{O}$ flux. The experimental chambers either contained $2.5 \mathrm{~L}$ of nonradioactive water (aquatic controls) or comprised a mesh screen upon which the lungfish was placed, overlying $1.3 \mathrm{~L}$ of water. After the 1 -h postinjection period, water samples $(10 \mathrm{~mL})$ were collected at $0,1,2,4,6,8,10,12$, and $18 \mathrm{~h}$. Water efflux was calculated based on the appearance of the radioactive ${ }^{3} \mathrm{H}-\mathrm{H}_{2} \mathrm{O}$ in the water. As an additional check of our protocol, ${ }^{3} \mathrm{H}-\mathrm{H}_{2} \mathrm{O}$ influx and efflux were compared using two subgroups of acutely (short-term; 4 h) or chronically (long-term; 6 mo) air-exposed lungfish. Unlike efflux, water influx determinations were based on the disappearance of ${ }^{3} \mathrm{H}-\mathrm{H}_{2} \mathrm{O}$ radioactivity following the addition of $10 \mu \mathrm{Ci}$ isotope to the underlying water. To verify that changes in water radioactivity were not due to evaporation, water samples were also taken from chambers spiked with ${ }^{3} \mathrm{H}$ $\mathrm{H}_{2} \mathrm{O}$ (as above) but containing no fish.

To determine whether subsequent reimmersion resulted in net stimulation of whole-body water turnover, ${ }^{3} \mathrm{H}-\mathrm{H}_{2} \mathrm{O}$ flux rate experiments were performed on lungfish during reimmersion after $20 \mathrm{wk}$ of air exposure. In these experiments, the isotope was injected intraperitoneally (as previously described) and followed by reimmersion in $2.5 \mathrm{~L}$ of water $1 \mathrm{~h}$ later. An initial water sample $(0 \mathrm{~h} ; 10 \mathrm{~mL})$ was then collected, followed by additional samples at 4,8 , and $12 \mathrm{~h}$. Care was taken to remove the cocoon from the water as it was shed by the lungfish. Nonterminal blood samples were collected from another group of animals after 8 or $24 \mathrm{~h}$ of reimmersion for determination of plasma osmolality.

Experiment 3: Unidirectional $\mathrm{Na}^{+}, \mathrm{Cl}^{-}$, and Acid-Base Equivalent Movements during Air Exposure and Reimmersion. To determine routine rates of $\mathrm{Na}^{+}$and $\mathrm{Cl}^{-}$net flux, influx, and efflux in aquatic lungfish, dual-label experiments were performed using ${ }^{22} \mathrm{Na}^{+}$and ${ }^{36} \mathrm{Cl}^{-}$as previously described (e.g., Wood 1988; Goss et al. 1992; Wilkie et al. 1998). Unlike the ${ }^{3} \mathrm{H}-\mathrm{H}_{2} \mathrm{O}$ efflux measurements, ion influx measurement was based on decreases in water radioactivity due to uptake of ${ }^{22} \mathrm{Na}^{+}$or ${ }^{36} \mathrm{Cl}^{-}$across the skin and/or gills (refer to "Analytical Techniques and Calculations" for additional details). Briefly, fish were held in chambers containing $2.5 \mathrm{~L}$ water that was moderately aerated to ensure adequate mixing of water and isotope. Fifteen minutes before initiating fluxes, $10 \mu \mathrm{Ci}$ of ${ }^{22} \mathrm{Na}^{+}$or $20 \mu \mathrm{Ci}^{36} \mathrm{Cl}^{-}$were added to the water. Water samples $(10 \mathrm{~mL})$ were subsequently taken at $0,2,4$, and $8 \mathrm{~h}$ after isotope addition. Although previously published studies used smaller amounts of isotope, it should be pointed out that the greater overall activities of ${ }^{22} \mathrm{Na}^{+}$ or ${ }^{36} \mathrm{Cl}^{-}$used in this experiment were needed to allow us to resolve unidirectional ion fluxes against the $2-\mathrm{mmol}^{-1} \mathrm{~L}^{-1}$ background $\mathrm{NaCl}$ concentrations. The net effect was that the specific 
activity of each isotope was approximately $2 \mu \mathrm{Ci}^{22} \mathrm{Na}^{+} / \mathrm{mmol}$ $\mathrm{Na}^{+}$and $4 \mu \mathrm{Ci}{ }^{36} \mathrm{Cl} / \mathrm{mmol} \mathrm{Cl}^{-}$, which was in the same range used in similar unidirectional flux studies (e.g., Wood 1988; Goss et al. 1992; Wilkie et al. 1998).

Ion fluxes were also performed on air-exposed animals, but in these experiments, ${ }^{22} \mathrm{Na}^{+}(10 \mu \mathrm{Ci})$ and ${ }^{36} \mathrm{Cl}^{-}(20 \mu \mathrm{Ci})$ were added to the bath water. Because the water was in direct contact with the ventral body surface, this allowed us to directly measure ion movements across this region of the lungfish body surface. After a 15-min mixing period, water samples were collected at $0,2,4$, and $8 \mathrm{~h}$ for later determination of radioactivity and ion concentrations. An empty chamber containing the same volume of water but spiked with ${ }^{22} \mathrm{Na}^{+}$and/or ${ }^{36} \mathrm{Cl}^{-}$ was used as a control. Because rehydration of the gills, a main site of ion regulation in most fish (Perry 1997; Marshall 2002), could also alter ion movements after reimmersion, recovery experiments in water that were similar to those described for ${ }^{3} \mathrm{H}-\mathrm{H}_{2} \mathrm{O}$ (above) were performed to track ion movements after $4 \mathrm{wk}$ of air exposure. In these experiments, water samples were taken at $0,2,4,8,12,16$, and $24 \mathrm{~h}$ after reimmersion.

To determine whether air exposure was associated with acidbase disturbances and subsequent correction after reimmersion, net acid movements $\left(J_{\text {net }}^{\mathrm{H}^{+}}\right)$were measured in five lungfish following reimmersion after 6 mo of air exposure. Because $J_{\text {net }}^{\mathrm{H}^{+}}$is the sum of the titratable acid flux $\left(J^{\mathrm{TA}}\right)$ and ammonia excretion $\left(J_{\text {amm }}\right)$, the titratable alkalinity and ammonia concentration was determined in water samples $(20 \mathrm{~mL})$ taken at $0,4,8$, and 12 $\mathrm{h}$ after reimmersion (cf. Wood 1988; Wilkie et al. 1998). Water ion concentrations were also measured to determine whether differences in the net fluxes of $\mathrm{Na}^{+}$versus $\mathrm{Cl}^{-}$could explain possible acid-base equivalent movements during reimmersion (Wood 1988; Wilkie et al. 1998).

\section{Analytical Techniques and Calculations}

Osmolality, Ions, and Nitrogenous Compounds. The osmolality of plasma samples $(10 \mu \mathrm{L})$ was determined using a Wescor 5100C (Logan, UT) vapor pressure osmometer. Plasma and water $\mathrm{Cl}^{-}$concentrations were measured using the mercuric thiocyanate assay (Zall et al. 1956), while $\mathrm{Na}^{+}$concentrations were determined by atomic absorption spectrophotometry (Varian Spectra AA-220 FS, Palo Alto, CA). Plasma ammonia levels were determined enzymatically (glutamate dehydrogenase reaction) using a commercial kit (Raichem ammonia reagent, product 85446; Hemagen, Columbia, MD), and plasma urea levels were determined using the modified diacetyl monoxime method (Rahmatullah and Boyde 1980). Muscle urea was analyzed in the same manner using muscle samples that had been ground to a fine powder under liquid $\mathrm{N}_{2}$, deproteinized in $6 \%$ perchloric acid, and then neutralized with $2 \mathrm{~N} \mathrm{KOH}$ (Wilkie et al. 1999). Plasma trimethylamine (TMA) and TMAO were measured using the ferrous sulfate/EDTA method (Weckell and Barnett 1991). Muscle water content was determined on pieces of the lateral trunk muscle $(\sim 100 \mathrm{mg})$ that had been dried to constant weight at $80^{\circ} \mathrm{C}$ for $5 \mathrm{~d}$ and expressed as $\mathrm{mL}$ water $\mathrm{g}^{-1}$ dry muscle.

${ }^{3} \mathrm{H}-\mathrm{H}_{2} \mathrm{O}$ Fluxes. Water efflux rates across the body surface were determined by first calculating the decreases in whole body radioactivity based on differences between water radioactivity at the beginning and end of the sampling period. This information was then used to determine the ${ }^{3} \mathrm{H}-\mathrm{H}_{2} \mathrm{O}$ efflux rate $\left(J^{3} \mathrm{H}_{-} \mathrm{H}_{2} \mathrm{O}\right)$ in counts per minute $(\mathrm{CPM}) \mathrm{kg}^{-1} \mathrm{~h}^{-1}$, using the following formula:

$$
J^{3}{\mathrm{H}-\mathrm{H}_{2} \mathrm{O}}=\frac{\mathrm{CPM}_{\mathrm{i}}-\mathrm{CPM}_{\mathrm{f}}}{T \times M},
$$

where $\mathrm{CPM}_{\mathrm{i}}$ and $\mathrm{CPM}_{\mathrm{f}}$ represent the initial and final CPM for a given flux period, $T$ is the flux period duration (h), and $M$ is the mass of the fish $(\mathrm{kg})$. The rates calculated in equation (1) were then used to determine the water efflux (clearance) rate as follows:

$$
\text { water efflux (clearance) rate }=\frac{J^{3} \mathrm{H}-\mathrm{H}_{2} \mathrm{O}}{Z} \text {, }
$$

where $Z$ equals the average $\mathrm{CPM} \mathrm{mL} \mathrm{m}^{-1}$ in each fish during each flux period in question and water efflux rate is expressed as $\mathrm{mL} \mathrm{kg} \mathrm{k}^{-1} \mathrm{~h}^{-1}$. Rate constants for exchangeable water efflux $(K)$ were then determined as described by Evans (1967), where

$$
K=2.3 \log _{10}\left(\frac{\mathrm{CPM}_{\mathrm{i}}}{\mathrm{CPM}_{\mathrm{f}}}\right)
$$

The $\mathrm{H}_{2} \mathrm{O}$ influx was determined by measuring the decreases in ${ }^{3} \mathrm{H}-\mathrm{H}_{2} \mathrm{O}$ mean specific activity after the addition of the isotope to the water, as described below for the determination of $\mathrm{Na}^{+}$ and $\mathrm{Cl}^{-}$influx. In all ${ }^{3} \mathrm{H}-\mathrm{H}_{2} \mathrm{O}$ experiments, water radioactivity was determined on $2.5-\mathrm{mL}$ water samples to which $5.0 \mathrm{~mL}$ of ACS fluor (Amersham, Buckinghamshire, UK) was added using a Rackbeta LKB1217 scintillation counter. Preliminary tests indicated that the quench was constant.

Unidirectional $\mathrm{Na}^{+}$and $\mathrm{Cl}^{-}$Fluxes. Determinations of the unidirectional flux of $\mathrm{Na}^{+}$and $\mathrm{Cl}^{-}$used approaches similar to those in previous studies (e.g., Wood 1988; Wilkie et al. 1998). Briefly, net $\mathrm{Na}^{+}\left(J_{\text {net }}^{\mathrm{Na}}\right)$ and $\mathrm{Cl}^{-}\left(J_{\text {net }}^{\mathrm{Cl}}\right)$ movements were calculated to determine whether the fish were experiencing a net loss (negative $J_{\text {net }}^{\text {ion }}$ ) or net gain (positive $J_{\text {net }}^{\text {ion }}$ ) of $\mathrm{Na}^{+}$and/or $\mathrm{Cl}^{-}$ from their bodies, using the following formula:

$$
J_{\text {net }}^{\text {ion }}=\frac{\left([\text { ion }]_{\mathrm{i}}-[\text { ion }]_{\mathrm{f}}\right) \times V}{T \times M},
$$


where $[\text { ion }]_{\mathrm{i}}$ and $[\text { ion }]_{\mathrm{f}}$ represent the concentrations of "cold" (nonradioactive) $\mathrm{Na}^{+}$or $\mathrm{Cl}^{-}$in the water at the beginning and end of a flux period, respectively; $V$ is the volume of water $(\mathrm{mL})$ in the container; and $T$ and $M$ are as previously stated.

Rates of $\mathrm{Na}^{+}\left(J_{\text {in }}^{\mathrm{Na}}\right)$ and $\mathrm{Cl}^{-}$influx $\left(J_{\text {in }}^{\mathrm{Cl}}\right)$ were based on reductions in water radioactivity during each flux period as described by

$$
J_{\text {in }}^{\text {ion }}=\frac{\left(\mathrm{CPM}_{\mathrm{i}}-\mathrm{CPM}_{\mathrm{f}}\right) \times V}{\mathrm{MSA} \times M \times T},
$$

where $\mathrm{CPM}_{\mathrm{i}}$ and $\mathrm{CPM}_{\mathrm{f}}$ are the radioactivities for ${ }^{22} \mathrm{Na}^{+}$and ${ }^{36} \mathrm{Cl}^{-}$, respectively $\left(\mathrm{CPM} \mathrm{mL}{ }^{-1}\right)$; MSA is the mean specific activity of each isotope in the external water $\left(\mathrm{CPM} \mu \mathrm{mol}^{-1}\right)$; and $V, M$, and $T$ are as previously stated. Back-flux correction (Wood 1988) was not required because internal CPM never exceeded $10 \%$ of the total CPM in the water during any given period. Because ${ }^{22} \mathrm{Na}^{+}$emits both gamma and beta radiation, while ${ }^{36} \mathrm{Cl}^{-}$emits only beta radiation, water samples $(2.5 \mathrm{~mL})$ were first counted on a Packard 5000 series gamma counter to determine the radioactivity due to ${ }^{22} \mathrm{Na}^{+}$. Thereafter, $5 \mathrm{~mL}$ of ACS scintillation fluor was added to the samples, which were left overnight to minimize chemiluminescence, before total $\mathrm{CPM}$ was determined the following morning via scintillation counting. Tests again demonstrated that quench was constant. The CPM due to ${ }^{36} \mathrm{Cl}^{-}$was based on the difference between the total scintillation CPM $\left({ }^{22} \mathrm{Na}^{+}\right.$plus $\left.{ }^{36} \mathrm{Cl}^{-}\right)$and the gamma $\mathrm{CPM}\left({ }^{22} \mathrm{Na}^{+}\right.$only) after correcting for differences in the counting efficiencies between the gamma counter and the scintillation counter.

Net Acid Flux after Reimmersion. The measurement of $J_{\text {net }}^{\mathrm{H}^{+}}$is described by the following relationship:

$$
J_{\mathrm{net}}^{\mathrm{H}^{+}}=J^{\mathrm{TA}}+J_{\mathrm{amm}}
$$

where $J^{\mathrm{TA}}$ is the titratable acid flux and $J_{\text {amm }}$ is the ammonia excretion rate. The $J^{\mathrm{TA}}$ was based on the difference in titratable alkalinity between the beginning and end of a sample period, where titratable alkalinity was measured by titrating water samples $(10 \mathrm{~mL}$; refrigerated for no more than $24 \mathrm{~h})$ to an end point of $\mathrm{pH} 4.0$, using analytical grade $0.02 \mathrm{~mol} \mathrm{~L}^{-1} \mathrm{HCl}$ (Sigma). Differences in water ammonia concentrations between the beginning and end of a flux period were used to calculate $J_{\text {amm }}$ (see Wood 1988; Wilkie et al. 1998 for further details).

\section{Statistical Analyses}

All data are expressed as the mean \pm 1 SEM. Where appropriate, data were analyzed using unpaired $t$-tests or either oneway or repeated-measures ANOVA followed by a Tukey posttest. In instances where the data were not normally distributed, a nonparametric ANOVA followed by Dunn's multiple com- parisons test was performed. Significance was determined at the $P<0.05$ level.

\section{Results}

Effects of Air Exposure on Osmolality, Urea, Ions, and Body Mass

Air exposure was characterized by the formation of a cocoon that covered the dorsolateral body surface of Protopterus dolloi. Under these conditions, most fish exhibited very little movement, but in a few instances it was clear that fish had shifted positions without damaging the cocoon. In addition, the fish sometimes responded to external stimuli (e.g., sudden noises, jarring of the container) with slight body movements and the occasional grunting sound.

Plasma osmolality was unaffected by air exposure in the slender lungfish, fluctuating around 240-260 $\mathrm{mOsm} \mathrm{kg}^{-1}$ under aquatic conditions and after 1, 4, and 20 wk of air exposure (Fig. 1A). This was despite a seven- to eightfold increase in mean plasma urea after 4 and 20 wk of air exposure (Fig. 1B), during which times individual values approached $100 \mathrm{mmol}$ urea- $\mathrm{N} \mathrm{L}^{-1}$ in some fish (range $=12-104 \mathrm{mmol}$ urea- $\mathrm{N} \mathrm{L}^{-1}$ ). Despite the high plasma urea concentrations, the counterbal-

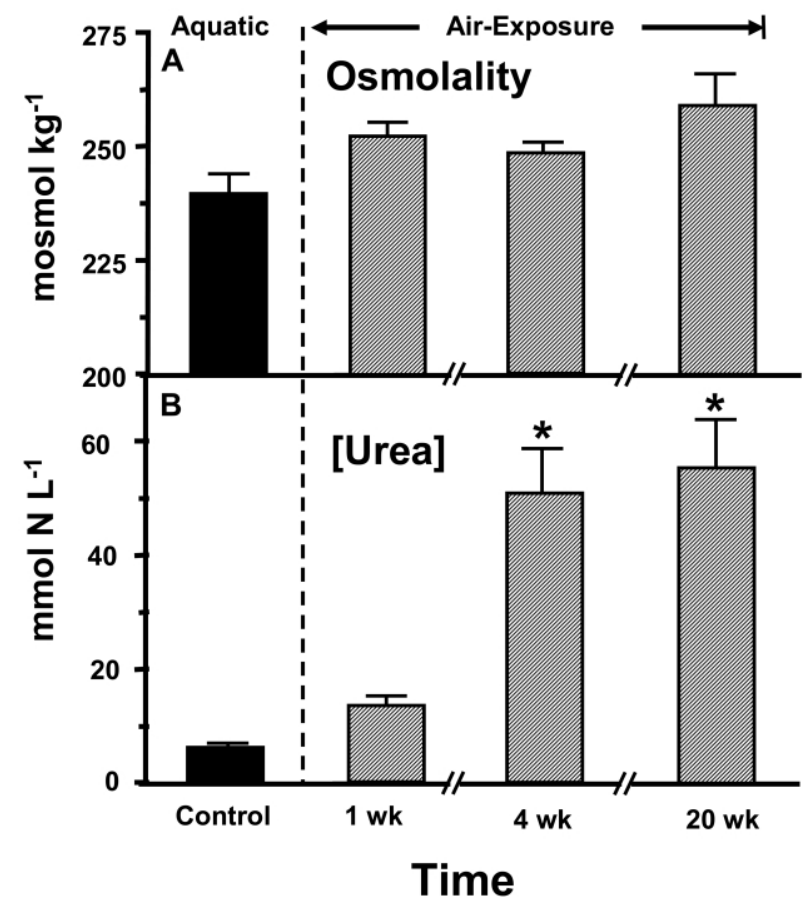

Figure 1. Differences in plasma osmolality $(A)$ and urea concentrations $(B)$ in the slender African lungfish (Protopterus dolloi) under aquatic conditions (solid bar; $N=7$ ), and after air exposure (hatched bars) for $1 \mathrm{wk}(N=6), 4 \mathrm{wk}(N=11)$, or $20 \mathrm{wk}(N=15)$. Data presented as the mean +1 SEM. Asterisks denote statistically significant differences from animals held under aquatic conditions $(<0.05)$. 
Table 1: Plasma $\mathrm{Na}^{+}$and $\mathrm{Cl}^{-}$concentrations and hematocrit measured in the slender African lungfish (Protopterus dolloi) during $20 \mathrm{wk}$ of air exposure

\begin{tabular}{llllr}
\hline \multicolumn{5}{c}{ Air Exposure } \\
\cline { 2 - 5 } & Aquatic & 1 wk & 4 wk & 20 wk \\
\hline$\left[\mathrm{Na}^{+}\right]\left(\mathrm{mmol} \mathrm{L}^{-1}\right)$ & $99.2 \pm 3.4(8)$ & $105.0 \pm 1.8(5)$ & $99.9 \pm 2.8(10)$ & $103.6 \pm 1.9(15)$ \\
{$\left[\mathrm{Cl}^{-}\right]\left(\mathrm{mmol} \mathrm{L}^{-1}\right)$} & $88.2 \pm 5.0(8)$ & $98.5 \pm 3.1(5)$ & $82.8 \pm 3.1(9)$ & $84.4 \pm 4.0(15)$ \\
$\mathrm{Hematocrit}(\%)^{30.4 \pm 1.2(5)}$ & $\ldots$ & $29.2 \pm 1.8(5)$ & $31.0 \pm 1.9(5)$ \\
\hline
\end{tabular}

Note. Data expressed as the mean \pm 1 SEM; sample sizes are in parentheses.

ancing solute TMAO and its precursor TMA were below limits of detection in the plasma in aquatic animals $(N=3)$ and in animals that were subject to $4 \mathrm{wk}(N=3)$ or $20 \mathrm{wk}$ of air exposure $(N=3)$. As a result, no further analysis for either TMAO or TMA was conducted. No significant changes in plasma ammonia were observed; in both aquatic and airexposed animals, ammonia fluctuated between 100 and 200 $\mu \mathrm{mol} \mathrm{L}{ }^{-1}$ (data not shown).

Plasma $\mathrm{Na}^{+}$and $\mathrm{Cl}^{-}$concentrations were stable under terrestrial conditions compared with aquatic conditions, ranging from 100 to $105 \mathrm{mmol} \mathrm{L}^{-1}$ and 83 to $99 \mathrm{mmol} \mathrm{L}^{-1}$, respectively (Table 1). Similarly, blood hematocrit was also unaltered during air exposure, averaging approximately $30 \%$ under aquatic and terrestrial conditions (Table 1).

In contrast to the plasma, muscle water content was 5.85 $\mathrm{mL} \mathrm{g}^{-1}$ dry muscle after 20 wk of air exposure, which was $56 \%$ greater than that measured in lungfish held under aquatic conditions. Muscle water content was not significantly different from that of aquatic animals after 4 wk of air exposure, however (Fig. 2A). There was substantial urea accumulation in the muscle during air exposure, which had increased by fivefold after $4 \mathrm{wk}$. Most notable was that the eightfold greater muscle urea concentrations observed in lungfish that were exposed to air for 20 wk (Fig. 2B) coincided with the much greater water content that was observed in the muscle at this time (Fig. 2A).

There was little change in body mass during $4 \mathrm{wk}$ of air exposure, with the greatest differences occurring after 1 wk, during which time body mass significantly decreased by almost 4\%. Although body mass was approximately 5\% lower after 4 wk of air exposure, it was similar to original values after 20 wk (Fig. 3A). On reimmersion after $20 \mathrm{wk}$, body mass was stable for the first $4 \mathrm{~h}$ but decreased steadily thereafter. By 8 h, mass had significantly decreased by $5 \%$, and by $24 \mathrm{~h}$ it was $20 \%$ lower than at the beginning of reimmersion (Fig. $3 B$ ). By $72 \mathrm{~h}$, the body mass appeared to have stabilized (Fig. $3 B$ ).

\section{${ }^{3} \mathrm{H}-\mathrm{H}_{2} \mathrm{O}$ Fluxes}

Following IP injection of ${ }^{3} \mathrm{H}-\mathrm{H}_{2} \mathrm{O}$, the water efflux rate across the body surface of the lungfish was approximately $130 \mathrm{~mL}$ $\mathrm{kg}^{-1} \mathrm{~h}^{-1}$ (Fig. 4), with a rate constant $(K)$ of $17.6 \% \mathrm{~h}^{-1}$ (Table 2). After acute transfer to terrestrial conditions, water efflux did not significantly change over the first $4 \mathrm{~h}$. In contrast, water efflux was about $65 \%$ lower in animals that had been air exposed for 6 mo (Fig. 4). When rates of water influx were determined by adding ${ }^{3} \mathrm{H}-\mathrm{H}_{2} \mathrm{O}$ to the water contacting the ventral skin, water influx rates were similar to the water efflux rates measured in animals immediately after air exposure. However, water influx was slightly lower than efflux in the group that

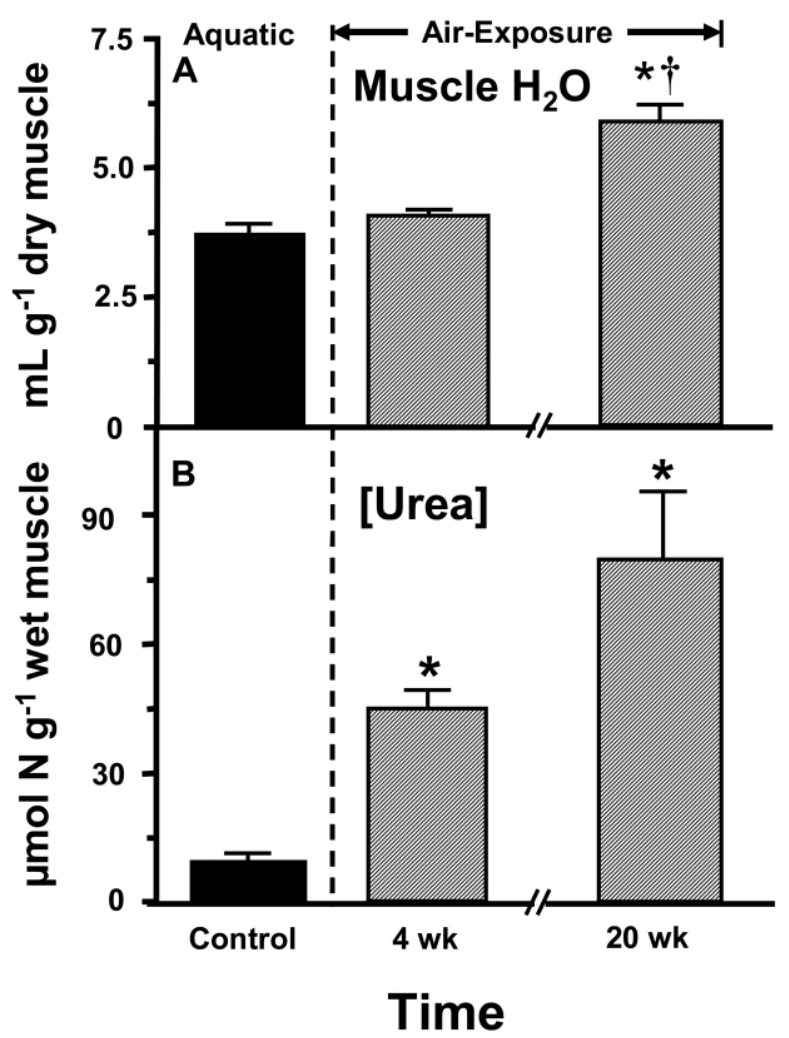

Figure 2. Differences in muscle water content $(A)$ and urea concentrations $(B)$ in the slender African lungfish (Protopterus dolloi) under aquatic conditions (solid bar; $N=5$ ) and after air exposure (hatched bars) for $4 \mathrm{wk}(N=5)$ or $20 \mathrm{wk}(N=5)$. Water content expressed as $\mathrm{mL}$ of $\mathrm{H}_{2} \mathrm{O}$ g dry muscle ${ }^{-1}$. Data presented as the mean +1 SEM. Asterisks denote statistically significant differences from animals held under aquatic conditions $(P<0.05)$, while the dagger indicates water contents significantly different from values measured after $4 \mathrm{wk}$ of air exposure. 


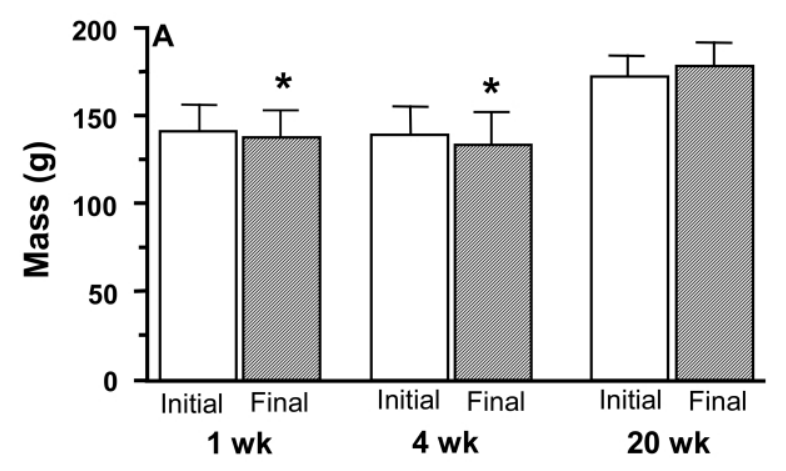

Time Air-Exposed

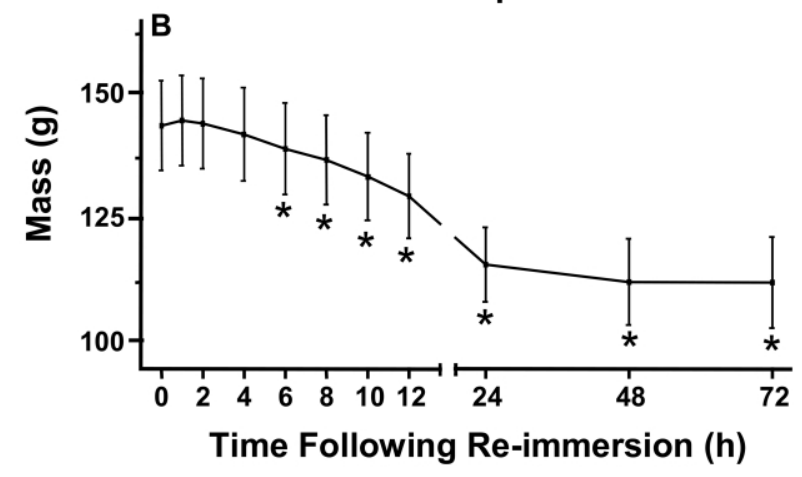

Figure 3. Changes in the wet body mass (g) of Protopterus dolloi after 1,4 , or $20 \mathrm{wk}$ of air exposure $(A ; N=6-10)$ and after reimmersion after $20 \mathrm{wk}$ of air exposure $(B ; N=4)$. Data expressed as the mean \pm 1 SEM. Asterisks indicate statistically significant differences between the initial and final masses measured in animals before and after 1, 4, or 20 wk of air exposure $(A)$ or significant differences from mass measured at the beginning of the reimmersion period $(B ; 0 \mathrm{~h}$; $P<0.05)$.

was chronically air exposed for 6 mo (Fig. 4). Since the gills were not immersed, both the water influx and efflux data confirmed that water exchange was taking place across the ventral surface of the animals, the only region of the body in contact with the water.

Although water efflux continued after air exposure, it was significantly reduced (by 55\%) within $1 \mathrm{wk}$ and remained depressed over 6 mo of air exposure, fluctuating between 45 and $60 \mathrm{~mL} \mathrm{~kg}^{-1} \mathrm{~h}^{-1}$ (Fig. 5), at which time $K$ ranged between $5.0 \%$ and $8.0 \% \mathrm{~h}^{-1}$ (Table 2). When a subgroup of fish were reimmersed after $20 \mathrm{wk}$ of air exposure, there was a three-andone-half- to fourfold increase in water turnover during the first $12 \mathrm{~h}$ (Fig. 6A), but plasma osmolality was unaltered (Fig. 6B).

\section{Unidirectional $\mathrm{Na}^{+}$and $\mathrm{Cl}^{-}$Fluxes}

Under aquatic conditions, the lungfish maintained both $\mathrm{Na}^{+}$ and $\mathrm{Cl}^{-}$balance, as both $J_{\text {net }}^{\mathrm{Na}}$ and $J_{\text {net }}^{\mathrm{Cl}}$ were not significantly different from 0 . The $J_{\mathrm{in}}^{\mathrm{Na}}$ averaged $15 \mu \mathrm{mol} \mathrm{kg}{ }^{-1} \mathrm{~h}^{-1}$, with a corresponding efflux rate of $-10 \mu \mathrm{mol} \mathrm{kg}^{-1} \mathrm{~h}^{-1}$ (Fig. 7A). The
$J_{\text {in }}^{\mathrm{Cl}}$ averaged $20 \mu \mathrm{mol} \mathrm{kg}{ }^{-1} \mathrm{~h}^{-1}$ but in some instances was undetectable, and the corresponding rate of $\mathrm{Cl}^{-}$efflux averaged $-75 \mu \mathrm{mol} \mathrm{kg}^{-1} \mathrm{~h}^{-1}$ (Fig. 7 B). Acute air exposure for $8 \mathrm{~h}$ led to net $\mathrm{Na}^{+}$losses of approximately $-50 \mu \mathrm{mol} \mathrm{kg}^{-1} \mathrm{~h}^{-1}$, but $\mathrm{Cl}^{-}$balance was maintained (Fig. 7). The net $\mathrm{Na}^{+}$losses were mainly due to an increase in efflux, which increased 10-fold during the initial $8 \mathrm{~h}$ of air exposure, while $J_{\mathrm{in}}^{\mathrm{Na}}$ averaged approximately $40 \mu \mathrm{mol} \mathrm{kg}{ }^{-1} \mathrm{~h}^{-1}$ but was not significantly different from aquatic (pre-air-exposure) rates (Fig. 7A). Following 6 mo of air exposure, neither $J_{\text {net }}^{\mathrm{Na}}$ nor $J_{\text {net }}^{\mathrm{Cl}}$ was significantly different

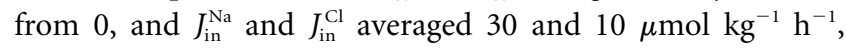
respectively (Fig. 7).

On reimmersion after $4 \mathrm{wk}$ of air exposure, when gill perfusion and function were presumably resumed (see "Discussion"), there was an elevation of $J_{\mathrm{in}}^{\mathrm{Na}}$, which increased by eightfold over the first $4 \mathrm{~h}$ (Fig. 8A). Although $J_{\mathrm{in}}^{\mathrm{Na}}$ fluctuated between 30 and $60 \mu \mathrm{mol} \mathrm{kg}{ }^{-1} \mathrm{~h}^{-1}$ between 4 and $24 \mathrm{~h}$, these rates were not significantly different from air-exposed (and aquatic) values (Fig. 8A). Despite greater variability, no significant changes in $J_{\text {in }}^{\mathrm{Cl}}$ were observed on reimmersion (Fig. $8 B$ ).

Net ion losses and acidic equivalent movements were also examined after reimmersion. Although the first $4 \mathrm{~h}$ were characterized by a significant net loss of $\mathrm{Cl}^{-}$in these fish (Table 3), $J_{\text {net }}^{\mathrm{Na}}$ was unaffected. This resulted in a predicted net $\mathrm{H}^{+}$loss (predicted net $\mathrm{H}^{+}$loss $=J_{\text {net }}^{\mathrm{Cl}}-J_{\text {net }}^{\mathrm{Na}}$; Wood 1988) of approximately $-290 \mu \mathrm{mol} \mathrm{kg}^{-1} \mathrm{~h}^{-1}$ (Table 3). Similarly, actual net $\mathrm{H}^{+}$ excretion over this same $0-4 \mathrm{~h}$ reimmersion period was approximately $-180 \mu \mathrm{mol} \mathrm{kg}^{-1} \mathrm{~h}^{-1}$ (Table 3 ). This net $\mathrm{H}^{+}$ex-

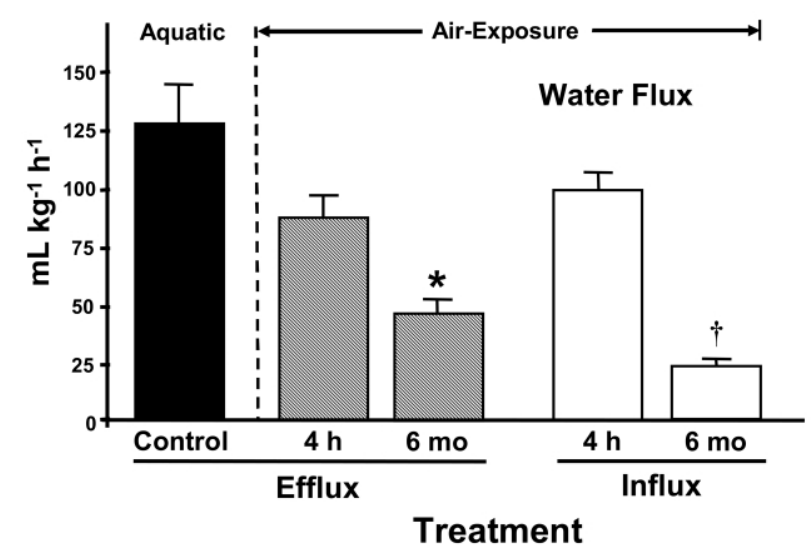

Figure 4. Water flux measured in Protopterus dolloi held under aquatic conditions $(N=8)$, or after acute $(4 \mathrm{~h} ; N=5)$ or chronic (6 mo; $N=4-5)$ air exposure. The rates of water efflux were measured in aquatic (solid bar) and air-exposed animals after intraperitoneal injection of ${ }^{3} \mathrm{H}-\mathrm{H}_{2} \mathrm{O}$ (hatched bars). For comparison, water influx was also determined in air-exposed animals (open bars) after direct addition of ${ }^{3} \mathrm{H}-\mathrm{H}_{2} \mathrm{O}$ to the water (see text for details). Data presented as the mean +1 SEM. The asterisk denotes a statistically significant difference from animals held under aquatic conditions, while the dagger denotes a significant difference between influx and efflux in the chronically (6 mo) air-exposed lungfish $(P<0.05)$. 
Table 2: Rate constants for water efflux $(K)$ in aquatic and air-exposed Protopterus dolloi, Protopterus annectens, and some other freshwater fish

\begin{tabular}{|c|c|c|}
\hline & $K\left(\%\right.$ Body Water $\left.\mathrm{h}^{-1}\right)$ & Reference \\
\hline \multicolumn{3}{|l|}{ Lungfish: } \\
\hline \multicolumn{3}{|l|}{ Protopterus dolloi: } \\
\hline Aquatic & $17.6 \pm .06(8)$ & This study \\
\hline \multicolumn{3}{|l|}{ Air-exposed: } \\
\hline $4 \mathrm{~h}$ & $11.8 \pm 1.1(5)^{\star}$ & This study \\
\hline $1 \mathrm{wk}$ & $7.4 \pm 1.0(6)^{\star}$ & This study \\
\hline $4 \mathrm{wk}$ & $4.9 \pm .9(6)^{*}$ & This study \\
\hline $20 \mathrm{wk}$ & $7.7 \pm .6(6)^{*}$ & This study \\
\hline $6 \mathrm{mo}$ & $6.1 \pm .8(5)^{\star}$ & This study \\
\hline Protopterus annectens (aquatic) & 44.1 & Oduleye 1977 \\
\hline \multicolumn{3}{|l|}{ Teleosts: } \\
\hline Yellow eel (Anguilla anguilla) & 8.6 & Evans 1969 \\
\hline Silver eel (Anguilla anguilla) & 8.0 & Evans 1969 \\
\hline Three-spine stickleback (Gasterosteus aculeatus) & 11.0 & Evans 1969 \\
\hline Roach (Rutilus rutilus) & 13.0 & Evans 1969 \\
\hline Brown trout (Salmo trutta) & 27.0 & Evans 1969 \\
\hline Atlantic salmon (Salmo salar) & 47.5 & Potts et al. 1970 \\
\hline Goldfish (Carassius auratus) & 74.0 & Maetz 1970 \\
\hline Killifish (Fundulus kansae) & 138.0 & Potts and Fleming 1970 \\
\hline Tilapia (Tilapia mossambica) & 186.0 & Potts et al. 1967 \\
\hline
\end{tabular}

Note. Rate constants $(K)$ for aquatic lungfish and teleosts are based on the combined efflux across the gills and skin, plus renal water losses; data from air-exposed $P$. dolloi represent efflux across the ventral body surface only. Data from this study are expressed as the mean \pm 1 SEM. Sample sizes in parentheses.

* Statistically significant differences from aquatic values $(P<0.05)$.

cretion was mainly attributable to a lower uptake of titratable acid across the body surface, as rates of ammonia excretion were unchanged. Beyond $4 \mathrm{~h}$, there were no further significant changes in net ion or net acid movements by the fish (Table 3).

\section{Discussion}

The Slender African Lungfish Maintains Osmotic and Electrolyte Balance during Air Exposure

The slender lungfish Protopterus dolloi has a remarkable ability to withstand air exposure under humid conditions for up to $6 \mathrm{mo}$, with no perturbation to osmotic and ion homeostasis. A key adaptation appears to be an ability to use the ventral body surface to take up water and ions from the thin layer of water lining the bottoms of their containers during air exposure. Under aquatic conditions, values of plasma osmolality, $\mathrm{Na}^{+}$, and $\mathrm{Cl}^{-}$were similar to values previously reported in $P$. dolloi (Ip et al. 2005) and its congener, Protopterus aethiopicus (Delaney et al. 1977). The ability of $P$. dolloi to produce a cocoon during air exposure is also shared with other species of Protopterus (e.g., Smith 1931; Janssens 1964; DeLaney et al. 1977). However, the absence of any change in osmolality, plasma ions $\left(\mathrm{Na}^{+}\right.$and $\left.\mathrm{Cl}^{-}\right)$, or hematocrit during air exposure in $P$. dolloi was in marked contrast to reports that other African lungfish experienced pronounced increases in some or all of these parameters over similar or longer periods of estivation in the laboratory (Smith 1931; Janssens 1964; Johansen et al. 1976b; DeLaney et al. 1977). These differences can probably be explained by the different air exposure methodologies used in the previous studies, in which the lungfish were held in jars or "estivation sacks" that permitted them to burrow into the mud, which was then gradually and completed dried out (Smith 1931; Janssens 1964; DeLaney et al. 1977). These previous findings led to a proposal that cocoon formation might be triggered by internal desiccation (Fishman et al. 1986). Because the slender lungfish we examined formed cocoons while maintaining internal osmotic and ionic balance while exposed to air under relatively humid conditions, it suggests that internal desiccation may not in fact be a stimulus for cocoon formation and estivation in the lungfish.

Plasma urea concentrations in aquatic $P$. dolloi were comparable with concentrations in previous studies on this species (Lim et al. 2004; Ip et al. 2005; Wood et al. 2005) as well as $P$. aethiopicus (Smith 1930; DeLaney et al. 1977; Loong et al. 2005) and Protopterus annectens (Loong et al. 2005). The magnitude of plasma urea elevation was comparable with increases previously reported in this species during air exposure (Ip et al. 


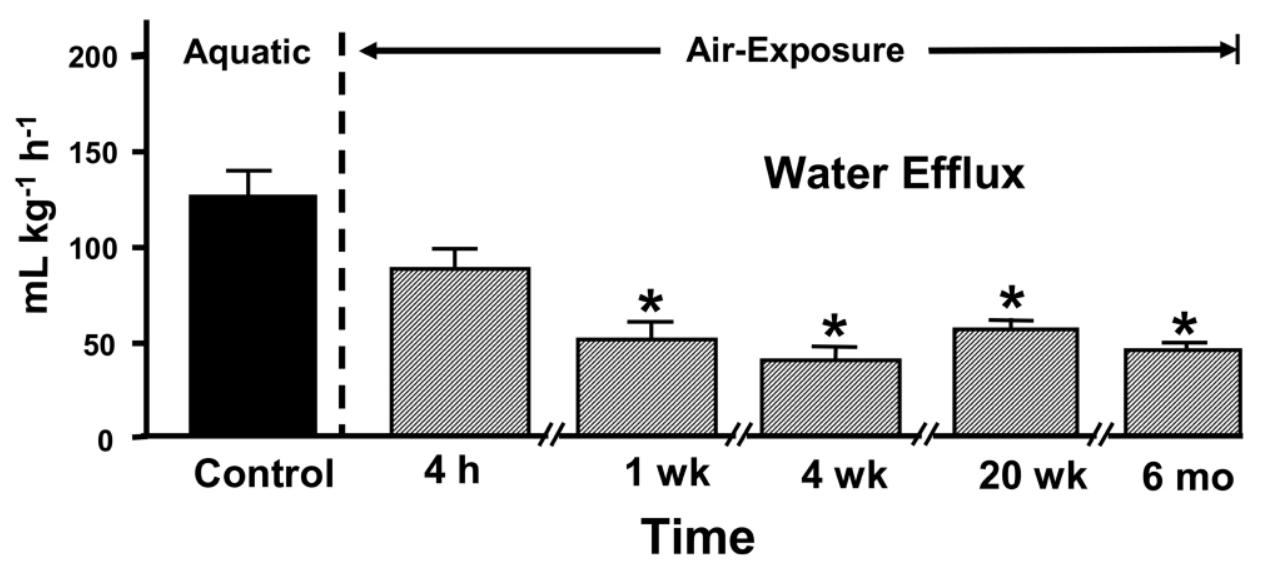

Figure 5. Water efflux measured in Protopterus dolloi held under aquatic conditions (solid bar, $N=8$ ) and after air exposure (hatched bars) for $4 \mathrm{~h}(N=5)$, $1 \mathrm{wk}(N=6), 4 \mathrm{wk}(N=6), 20 \mathrm{wk}(N=8)$, or $6 \mathrm{mo}(N=5)$. Data presented as the mean +1 SEM. Asterisks denote statistically significant differences from animals held under aquatic conditions $(P<0.05)$. Note that the rates of efflux under aquatic conditions and after $4 \mathrm{~h}$ and 6 mo of air exposure were presented in Figure 4, but they were replotted here for reference.

2005; Wood et al. 2005) but less than in other species of estivating Protopterus (Smith 1930; Janssens 1964; DeLaney et al. 1977; Ip et al. 2005). The accumulation of urea may not have been as great in our study as in fully estivating lungfish due to extrabranchial urea excretion. Indeed, recent divided-chamber experiments have revealed that extrabranchial urea excretion sites such as the skin and/or renal routes made equal contributions to ammonia and urea excretion in water (Wood et al. 2005). Although significant renal urea excretion is less likely in air, due to the possibility of oliguria (cessation of urination; Smith 1930; DeLaney et al. 1977), it is likely that significant cutaneous urea excretion did occur, as recently demonstrated in air-exposed $P$. dolloi by Wood et al. (2005).

Functioning as an osmolyte, urea retention would lower the vapor pressure of the body fluids (Kirschner 1991), leading to lower rates of evaporative water loss in the air-exposed lungfish. However, its accumulation in the muscle could also generate critical osmotic gradients to promote water entry into this compartment during air exposure. Thus, the muscle could serve as a "water reservoir" that could release water to the interstitial space and plasma if the osmolality of the extracellular fluid were to increase during prolonged air exposure or estivation. Collectively, these strategies could delay the onset of hemoconcentration, that is, osmotic and ionic disturbances that are characteristic of estivation in lungfish (Delaney et al. 1976, 1977; Johansen et al. 1976b). Indeed, P. dolloi live in marginal, swampy habitats where they may be subject to temporary periods of air exposure during which the gills would be inoperative for osmo- or ionoregulation. Under such conditions, water and ion uptake through the ventral body surface and urea accumulation and water storage in the muscle could be essential for maintaining osmotic and ionic homeostasis.

In lungfish undergoing prolonged (several months) estiva- tion, desiccation (e.g., Johansen et al. 1976b; DeLaney et al. 1977) probably leads to contraction of the extracellular and intracellular spaces, thereby concentrating urea. However, the extracellular and intracellular fluid volumes are probably expanded by the above-described water uptake during air exposure in $P$. dolloi, which would dilute urea in the plasma and other body compartments. This explanation is supported by the $56 \%$ increase in muscle water content (Fig. $2 A$ ) observed after $20 \mathrm{wk}$ of air exposure and the high urea concentrations in this compartment (Fig. 2B). If it is assumed that the lungfish body mass was $60 \%$ muscle, this would be equal to a net water gain of $32.3 \mathrm{~mL}$ in a $100 \mathrm{-g}$ animal. Such a large increase in muscle water content would therefore mask a much larger increase in muscle urea content than the eightfold increase observed when wet muscle mass was considered (Fig. 2B). Indeed, when expressed per gram dry muscle, urea concentration increased 13-fold from approximately $44 \mu \mathrm{mol} \mathrm{g}{ }^{-1}$ dry muscle in aquatic animals to an average of $570 \mu \mathrm{mol} \mathrm{g}{ }^{-1}$ dry muscle after 20 wk air exposure.

Urea accumulation and subsequent water uptake and storage in the muscle by the lungfish also explains the smaller than expected losses of body mass after 4 wk and the absence of change in body mass observed after 20 wk air exposure and starvation in $P$. dolloi (Fig. 3). The approximately $20 \%$ decrease (31.6 g; Fig. $3 B$ ) in body mass during the first $48-72 \mathrm{~h}$ of reimmersion was probably due to increased water efflux, which would have been accompanied by very high rates of urea excretion following submersion (Smith 1930; Wood et al. 2005). Indeed, the period of greatest water loss was from 6 to $24 \mathrm{~h}$, which corresponds with the period of greatest urea excretion in P. dolloi during reimmersion reported by Wood et al. (2005). Further, the loss of body mass observed during reimmersion was equivalent to approximately $28 \mathrm{~mL} \mathrm{H}_{2} \mathrm{O}$ for a 100-g lung- 

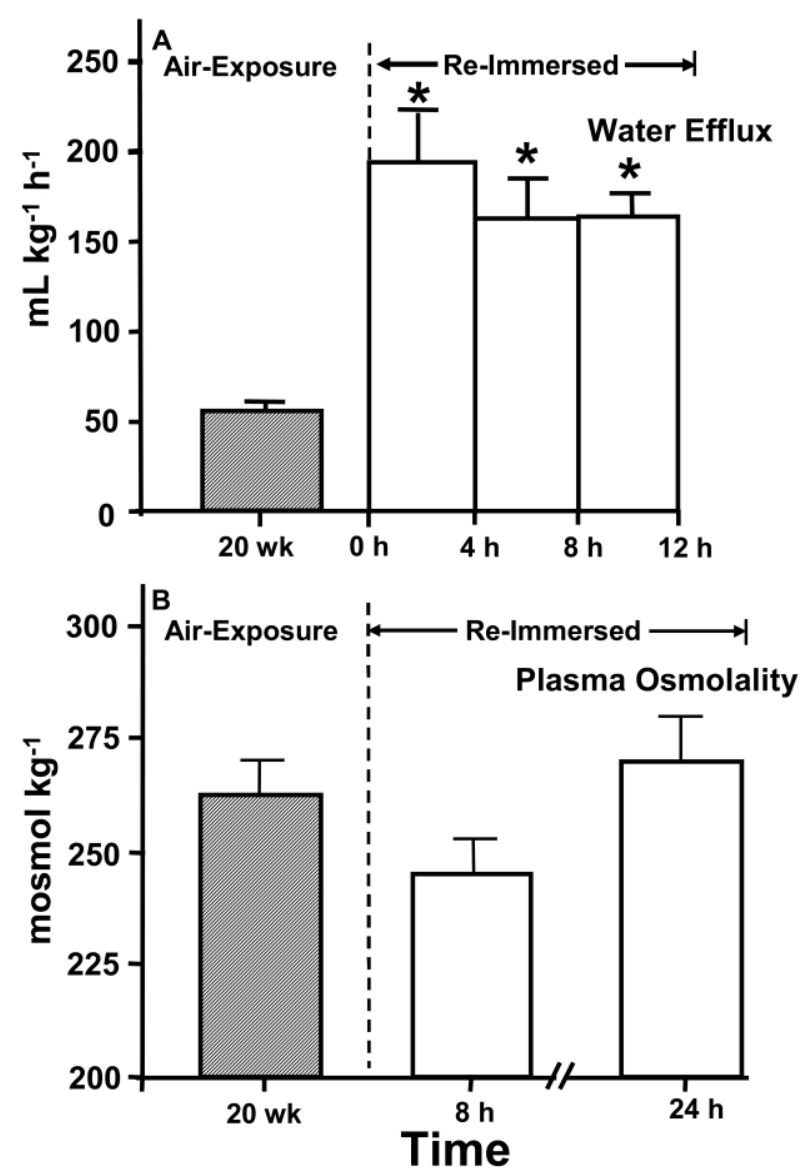

Figure 6. Differences in water efflux $(A)$ and plasma osmolality $(B)$ measured in Protopterus dolloi held under terrestrial conditions (hatched bar) and during the first $12-24 \mathrm{~h}$ after reimmersion (open bars). For water efflux, $N=8$ during air exposure and $N=4$ when reimmersed. For plasma osmolality measurements, $N=15$ for airexposed lungfish (replotted from Fig. 1 and included for reference) and $N=8$ after $8 \mathrm{~h}$ and $24 \mathrm{~h}$ of reimmersion. Data presented as the mean +1 SEM. Asterisks denote statistically significant differences from air-exposed animals $(P<0.05)$.

fish, which is very close to the net gain in muscle $\mathrm{H}_{2} \mathrm{O}(32.3$ $\mathrm{mL}$ ) calculated above, and lends further support to this "water unloading" hypothesis. The three- to fourfold increase in ${ }^{3} \mathrm{H}$ $\mathrm{H}_{2} \mathrm{O}$ efflux observed in reimmersed $P$. dolloi (Fig. 6A) also suggests that there was considerable water loss during reimmersion. It should also be noted that reimmersion was probably accompanied by diuresis, which would also contribute to net water loss during reimmersion and should be investigated in future studies.

At first glance, it may be difficult to reconcile how the mass gain by the air-exposed lungfish could exceed $20 \mathrm{~g}$ when the water volume lining the bottom of its chamber was only approximately $20 \mathrm{~mL}$. However, it should be noted that the water in the chamber was regularly replenished (weekly) over the 20- wk exposure period, thereby allowing the air-exposed lungfish to accumulate and store water in excess of $20 \mathrm{~mL}(20 \mathrm{~g})$. Indeed, similar factors likely explain why $P$. annectens lost little mass (only approximately $6 \%$ ) when estivated in the laboratory for approximately 6 mo (Janssens 1964). Although a cocoon was present in that study, weight loss was probably reduced because the mud into which the fish had burrowed was not dried out completely (Janssens 1964).

To offset urea's perturbing effects, the counterbalancing solute TMAO is also retained in the plasma and tissues of elasmobranchs (Ballantyne 1997; Yancey 2001). Although we suspected that TMAO could play a similar role in $P$. dolloi, we were unable to detect TMAO or its precursor TMA in the plasma. Perhaps there is little selective pressure to offset the possible inhibition of metabolic enzymes by urea because it might actually provide a mechanism of metabolic downregulation during air exposure and/or estivation (Smith 1930; Janssens 1964). Against this hypothesis is the work of Grundy and Storey (1994), who demonstrated that the kinetic properties of pyruvate kinase and phosphofructokinase in skeletal muscle homogenates of estivating spadefoot toads and nonestivating

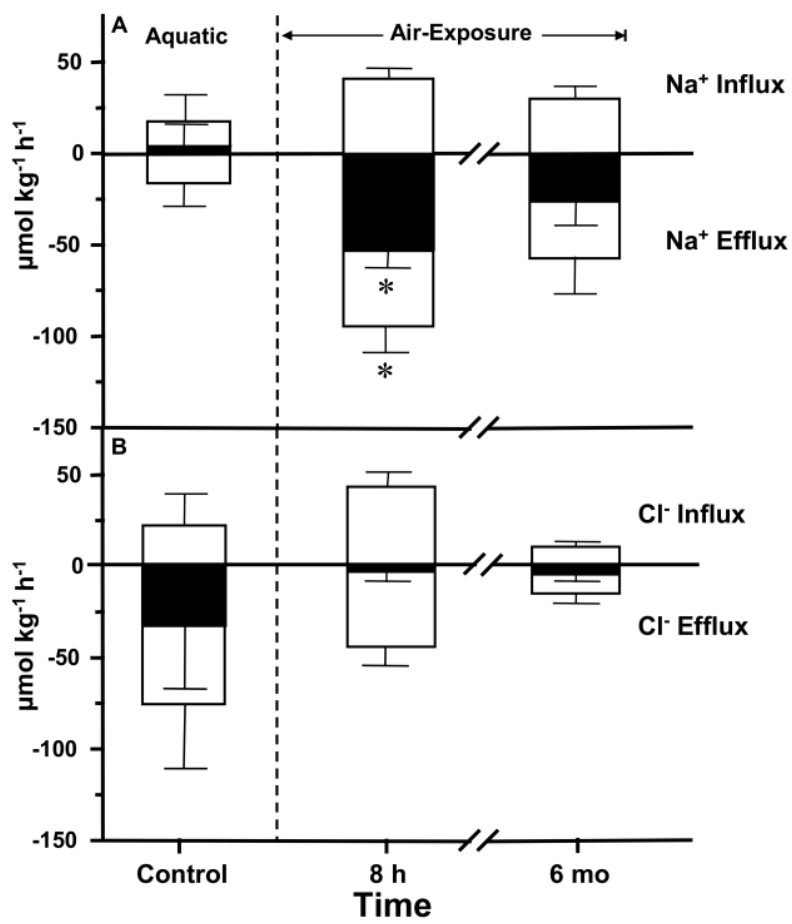

Figure 7. Unidirectional $\mathrm{Na}^{+}$and $\mathrm{Cl}^{-}$fluxes measured in Protopterus dolloi held under aquatic conditions $(N=4)$ and during acute air exposure for $8 \mathrm{~h}(N=6)$ or chronic air exposure for 6 mo $(N=5)$. Bars above the 0 baseline represent rates of ion influx $\left(J_{\text {in }}^{\mathrm{Na}}, J_{\text {in }}^{\mathrm{Cl}}\right)$; bars below the 0 baseline depict ion efflux $\left(J_{\text {out }}^{\mathrm{Na}}, J_{\text {out }}^{\mathrm{Cl}}\right)$, while solid bars represent the net flux $\left(J_{\text {net }}^{\text {ion }}=J_{\text {in }}^{\text {ion }}+J_{\text {out }}^{\text {ion }}\right)$. Data presented as the mean \pm 1 SEM. Asterisks denote statistically significant differences from animals held under aquatic conditions $(P<0.05)$. 


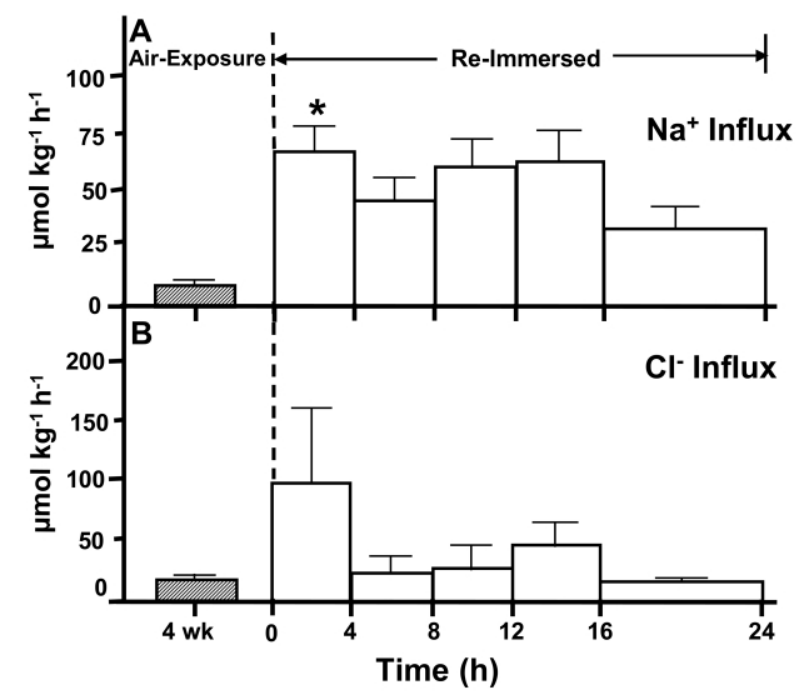

Figure 8. Rates of $\mathrm{Na}^{+}$influx $(A)$ and $\mathrm{Cl}^{-}$influx in (B) Protopterus dolloi after 4 wk of air exposure $(N=9)$ and the first $24 \mathrm{~h}$ following reimmersion $\left(N=15-16\right.$ for $J_{\text {in }}^{\mathrm{Na}} ; N=11$ for $\left.J_{\text {in }}^{\mathrm{Cl}}\right)$. Data presented as the mean +1 SEM. Asterisks denote statistically significant differences from air-exposed animals $(P<0.05)$.

leopard frogs (Rana pipiens) were virtually unaffected by urea (up to $600 \mathrm{mmol} \mathrm{N} \mathrm{L}^{-1}$ ) and TMAO. Studies on a greater number of amphibians and lungfish are clearly required to determine whether enzyme inhibition by urea is an important aspect of metabolic downregulation in at least some of these animals.

\section{Extrabranchial Route(s) of Water Exchange}

In water, the tritiated water flux constant $(K)$ was approximately $18 \% \mathrm{~h}^{-1}$. While low, this indicates that the overall water permeability of $P$. dolloi was merely at the low end of the range for freshwater fish (Table 2), somewhat surprising given the lungfish's greatly reduced gill (Burggren and Johansen 1986). Anatomically, the gills of Protopterus lack filaments and secondary lamellae on the anterior gill arches, and lamellar perfusion is drastically reduced to the posterior arches during air exposure and after lung breaths due to the opening of arterioarterial shunts (Laurent et al. 1978). Based on this evidence, we had hypothesized that water turnover would be lower than values reported in exclusively aquatic fish. As our data did not support this hypothesis, they suggest that an additional site of water exchange was the skin.

Few studies have examined the skin of lungfish (e.g., Kitzan and Sweeney 1968; Sturla et al. 2001, 2002). Graham (1997) reported that supradermal capillary density in $P$. annectens was comparable with the density in many frogs, in which the critical role of the skin for water uptake is firmly established (for reviews, see Toledo and Jared 1993; Jørgensen 1997). Tritiated water fluxes revealed appreciable water movement across the ventral body surface of $P$. dolloi during air exposure. Because water flux during initial air exposure (4 or $8 \mathrm{~h}$ ) was not significantly different from the aquatic condition, our findings suggest that the majority of water exchange is ventral, even when the animals are submersed in water. We also measured unidirectional water influx by tracking decreases in external ${ }^{3} \mathrm{H}-\mathrm{H}_{2} \mathrm{O}$ radioactivity that was added to the bath in acutely (4 h) and chronically (6 mo) air-exposed animals. Water influx approximately equaled water efflux measured in the acutely airexposed animals but was slightly lower in the chronically airexposed animals. Nevertheless, these findings not only validated our protocol but also confirmed our hypothesis of ventral water exchange (Fig. 4).

Sturla and colleagues (2001) demonstrated that the dorsal and ventral skin of $P$. annectens contains mitochondria-rich (MR) cells similar to those found in the fish gill. This indicates that the skin in African lungfish probably has an ionoregulatory role (see below), as has been well established in amphibian skin (e.g., Koefoed-Johnsen and Ussing 1958; Ehrenfeld and GarciaRomeu 1977; Ehrenfeld et al. 1989). Further, water and ion uptake are both known to take place in the ventral pelvic region of amphibians (pelvic patch; Toledo and Jared 1993), which also contains aquaporins, as recently demonstrated in the tree frog (Hyla japonica; Hasegawa et al. 2003). The possibility of an analogous ion and water transport region in lungfish offers potentially exciting insight on the mechanisms and evolution of ion and water transport in vertebrates.

A notable effect of air exposure was the persistent 40\%-70\% decrease in overall water flux across the ventral body surface after approximately $1 \mathrm{wk}$ (Fig. 5). Since plasma osmolality was stable during air exposure, the fish were more or less in an osmotic steady state by this time. Thus, the reduction in water flux might be a consequence of decreases in evaporative water loss due to complete formation of the water resistant cocoon covering the dorsolateral body surface. In some Australian desert frogs, African ranids, and South American frogs, cocoon formation reduced water loss by $80 \%-90 \%$ during prolonged estivation (Toledo and Jared 1993). Although the cocoon's role in reducing evaporative water loss in the lungfish is a frequent subject of speculation, we are aware of no studies that have quantified it. Regardless, our findings support the supposition that lungfish efficiently extract available water from their external surroundings to stay hydrated during air exposure and probably also during the initial stages of estivation.

\section{Ion Uptake Continues in Air}

Inspection of the electron micrographs and immunohistochemistry of the skin and gills of P. annectens (Sturla et al. 2001) suggests the MR cells are fewer in number and size compared to teleosts (Perry 1997; Marshall 2002). These observations, combined with the lungfish's reduced gill (Laurent et al. 
Table 3: Predicted and actual net acid fluxes $\left(\mu \mathrm{mol} \mathrm{kg}^{-1} \mathrm{~h}^{-1}\right)$ across the body surface of Protopterus dolloi after 6 mo of air exposure and during reimmersion

\begin{tabular}{|c|c|c|c|c|}
\hline & \multirow{2}{*}{$\begin{array}{l}\text { Terrestrial } \\
(N=9)\end{array}$} & \multicolumn{3}{|c|}{ Reimmersion $(N=5)$} \\
\hline & & $0-4 \mathrm{~h}$ & $4-8 \mathrm{~h}$ & $8-12 \mathrm{~h}$ \\
\hline Net $\mathrm{Cl}^{-}$flux & $-28.1 \pm 4.4$ & $-281.9 \pm 100.8^{\star}$ & $320.8 \pm 94.6$ & $-94.3 \pm 115.3$ \\
\hline Net $\mathrm{Na}^{+}$flux & $-6.6 \pm 2.4$ & $9.6 \pm 112.9$ & $-60.7 \pm 68.9$ & $-139.6 \pm 154.0$ \\
\hline Predicted net $\mathrm{H}^{+}$flux & $-21.6 \pm 2.9$ & $-291.4 \pm 169.2$ & $381.5 \pm 89.6$ & $45.2 \pm 128.8$ \\
\hline Titratable acid flux & $\ldots$ & $-8.3 \pm 38.6^{*}$ & $250.1 \pm 27.1$ & $155.0 \pm 37.9$ \\
\hline Ammonia flux & $\ldots$ & $-171.0 \pm 30.6$ & $-168.6 \pm 66.7$ & $-192.0 \pm 41.8$ \\
\hline Actual net $\mathrm{H}^{+}$flux & $\ldots$ & $-179.3 \pm 45.7^{\star}$ & $81.5 \pm 80.4$ & $-37.0 \pm 51.3$ \\
\hline
\end{tabular}

Note. Data expressed as the mean \pm 1 SEM.

* Significant difference from values measured during the 4-8-h and 8-12-h flux periods following reimmersion $(P \leq 0.05)$.

1978; Burggren and Johansen 1986), suggested that P. dolloi would have low basal rates of ion uptake. Indeed, rates of unidirectional $\mathrm{Na}^{+}$and $\mathrm{Cl}^{-}$influx were more than $90 \%$ lower than values typically measured in comparably sized freshwater fish ranging from lampreys (Wilkie et al. 1998) to teleosts (Evans 1979; Wood 1988; Goss et al. 1992). Influx was more or less balanced by similarly low rates of diffusive efflux (outflux) for both $\mathrm{Na}^{+}$and $\mathrm{Cl}^{-}$. These data suggest that, compared with gills in other freshwater fish, the lungfish gill has low ion permeability. Since lungfish are likely capable of surviving under a variety of harsh conditions, including acidic, hypoxic/ anoxic, and hypercapnic exposures, gills of low ion and gas permeability could be adaptive. In addition to preventing the diffusional loss of $\mathrm{O}_{2}$ across the gills to $\mathrm{O}_{2}$-depleted waters, diffusional uptake of $\mathrm{H}^{+}$(equals loss of $\mathrm{HCO}_{3}^{-}$) or $\mathrm{CO}_{2}$ would also be expected to be lower. Indeed, the nests used by $P$. dollo $i$ during the dry season and for breeding are characterized by low $\mathrm{pH}$ (4.7-6.5), high $\mathrm{CO}_{2}$, and low $\mathrm{O}_{2}$ (Brien et al. 1959, cited by Greenwood 1986).

Our data do differ from those of Oduleye (1977), who reported that the unidirectional efflux of $\mathrm{Na}^{+}$by $P$. annectens was approximately $250-500 \mu \mathrm{mol} \mathrm{kg}{ }^{-1} \mathrm{~h}^{-1}$ after injection of ${ }^{22} \mathrm{Na}^{+}$. One possible explanation for this discrepancy is interspecific variation between $P$. dolloi and $P$. annectens. Indeed, Perry et al. (2005) recently reported that unlike in $P$. annectens and $P$. aethiopicus (McMahon 1970; Burggren and Johansen 1986), most $\mathrm{CO}_{2}$ unloading in $P$. dolloi was via the lungs and not the gills. Other factors that might explain these discrepancies in ion efflux rates include differences in body size, life stage, and methodology (isotope injection vs. addition to the water [this study]).

Uptake of $\mathrm{Na}^{+}$and $\mathrm{Cl}^{-}$clearly occurred through the ventral skin during air exposure. The aforementioned presence of MR cells in both the dorsal and ventral skin of P. annectens (Sturla et al. 2001) is in accord with these data. Because MR cells are also present in amphibian skin (Ehrenfeld et al. 1989), our data complement the morphological findings of Sturla et al. (2001, 2002) and their prediction of a "convergence of strategies" of osmoregulation and ionoregulation between lungfish and amphibians.

The increase in $\mathrm{Na}^{+}$influx observed immediately after reimmersion was probably related to reperfusion of blood to the gills. Similar increases in urea excretion are also thought to be at least partially attributable to this factor in African lungfish (Smith 1930; Wood et al. 2005). It is tempting to speculate that the increase in $\mathrm{Na}^{+}$influx was related to the large surge of urea excretion $\left(2,000-4,000 \mu \mathrm{mol} \mathrm{kg}^{-1} \mathrm{~h}^{-1}\right)$, which reportedly occurs at this time and is proposed to involve facilitated and/or active urea transport (Wood et al. 2005), but more detailed examinations are needed.

The movements of $\mathrm{Na}^{+}$and $\mathrm{Cl}^{-}$might also be manipulated for the purpose of acid-base regulation after reimmersion. Due to the need to maintain electroneutrality, loss of either $\mathrm{Na}^{+}$or $\mathrm{Cl}^{-}$across an epithelial surface must be accompanied by respective losses of $\mathrm{HCO}_{3}^{-}$(or $\mathrm{H}^{+}$uptake as a counterion) or $\mathrm{H}^{+}$ (or $\mathrm{HCO}_{3}^{-}$uptake) according to the strong ion difference theory (Stewart 1983; Goss and Wood 1991). Although we did not measure internal acid-base status, the relatively short-term, slight stimulation of $J_{\text {net }}^{\mathrm{H}^{+}}$after reimmersion indicates that $\mathrm{pH}$ disturbances were probably minimal during air exposure. This slight stimulation of $J_{\text {net }}^{\mathrm{H}^{+}}$appeared to result from greater net $\mathrm{Cl}^{-}$versus $\mathrm{Na}^{+}$losses (Table 3). Between 8 and $12 \mathrm{~h}$, however, the fish appeared to be in acid-base balance when titratable acid uptake was balanced by the stable, outward ammonia flux.

\section{Implications of Water and Ion Uptake during Estivation}

In many animals, torpor and hibernation are methods of last resort in response to not only changes in water availability but also temperature extremes, resource limitations, and/or decreases in oxygen availability. Recovery from such drastic survival strategies can also be energetically expensive as animals attempt to reestablish homeostasis. In the African lungfish, estivation is the most extreme response to reductions in water availability. Our study demonstrates that the amphibian-like ability of $P$. dolloi to take up water and to exchange ions and 
acidic equivalents with its environment via the ventral body surface enables this fish to withstand less extreme and temporary shortages of water without having to enter estivation. Moreover, by minimizing internal osmotic and ionic disturbances during air exposure, the animals probably recover more rapidly after water restriction and therefore minimize energy expenditures during recovery. We propose that the combination of ventral skin water permeability and internal urea accumulation during air exposure allows $P$. dolloi to extract water from its surroundings and to store water in the muscle when water supply becomes limited. Since ammonia excretion continues during air exposure (Wood et al. 2005; Loong et al. 2005), our findings also suggest that the primary selective pressure for urea production and retention in estivating lungfish is water conservation rather than ammonia detoxification.

\section{Acknowledgments}

We thank Drs. C. Glover, L. Diao, S. Nadella, and R. Kent, and M. Patel for their invaluable assistance with sample collection and analysis, and M. Patel, C. Bucking, and the McMaster University Animal Care Staff for their assistance in the monitoring and care of our colony of Protopterus dolloi. We are also grateful to Dr. S. F. Perry, University of Ottawa; Dr. P. J. Walsh, University of Ottawa/University of Miami; and Dr. M. Grosell, University of Miami; for their helpful insight and suggestions. The constructive comments of two anonymous reviewers were also appreciated. This investigation was funded by a Natural Sciences and Engineering Research Council Discovery grant to C.M.W., who is also supported by the Canada Research Chair program.

\section{Literature Cited}

Ballantyne J.S. 1997. Jaws: the inside story. The metabolism of elasmobranch fishes. Comp Biochem Physiol B 118:703-742.

Burggren W.W. and K. Johansen. 1986. Circulation and respiration in lungfishes (Dipnoi). J Morphol 1(suppl.):217236.

Chew S.F., N.K.Y. Chan, A.M. Loong, K.C. Hiong, W.L. Tam, and Y.K. Ip. 2004. Nitrogen metabolism in the African lungfish (Protopterus dolloi) aestivating in a mucus cocoon on land. J Exp Biol 207:777-786.

Chew S.F., T.F. Ong, L. Ho, W.L. Tam, A.M. Loong, K.C. Hiong, W.P. Wong, and Y.K. Ip. 2003. Urea synthesis in the African lungfish Protopterus dolloi: hepatic carbamoyl phosphate synthetase III and glutamine synthetase are upregulated by 6 days of aerial exposure. J Exp Biol 206:3615-3624.

Delaney R.G., C. Chub, and A.P. Fishman. 1976. Hematologic observations on the aquatic and estivating African lungfish Protopterus aethiopicus. Copeia 3:423-434.

Delaney R.G., S. Lahiri, and A.P. Fishman. 1974. Aestivation of the African lungfish Protopterus aethiopicus: cardiovascular and respiratory functions. J Exp Biol 61:111-128.

Delaney R.G., S. Lahiri, R. Hamilton, and A.P. Fishman. 1977. Acid-base balance and plasma composition in the aestivating lungfish (Protopterus). Am J Physiol 23:R10-R17.

Ehrenfeld J. and F. Garcia-Romeu. 1977. Active hydrogen excretion and sodium absorption through isolated frog skin. Am J Physiol 233:F46-F54.

Ehrenfeld J., I. Lacoste, and B.J. Harvey. 1989. The key role of mitochondria-rich cell in $\mathrm{Na}^{+}$and $\mathrm{H}^{+}$transport across the frog skin epithelium. Pflüg Arch 414:59-67.

Evans D.H. 1967. Sodium, chloride, and water balance of the intertidal teleost, Xiphister atropurpureus. III. The roles of simple diffusion, exchange diffusion, osmosis and active transport. J Exp Biol 47:525-534.

- 1969. Studies on the permeability of selected marine, freshwater and euryhaline teleosts. J Exp Biol 50:689-703.

- 1979. Fish. Pp. 305-391 in G.M.O. Maloiy, ed. Comparative Physiology of Osmoregulation in Animals. Academic Press, New York.

Fishman A.P., A.I. Pack, R.G. Delaney, and R.J. Gallante. 1986. Estivation in Protopterus. J Morphol 1(suppl.):237-248.

Goss G.G., P. Laurent, and S.F. Perry. 1992. Evidence for a morphological component in acid-base regulation during environmental hypercapnia in the brown bullhead (Ictalurus nebulosus). Cell Tissue Res 268:539-552.

Goss G.G. and C.M. Wood. 1991. Two-substrate kinetic analysis: a novel approach linking ion and acid-base transport at the gills of freshwater trout, Oncorhynchus mykiss. J Comp Physiol B 161:635-646.

Graham J.B. 1997. Air-Breathing Fishes: Evolution, Diversity and Adaptation. Academic Press, San Diego, CA.

Greenwood P.H. 1986. The natural of history of African lungfishes. J Morphol 1(suppl.):163-179.

Grundy J.E. and K.B. Storey. 1994. Urea and salt effects on enzymes from estivating and non-estivating amphibians. Mol Cell Biochem 131:9-17.

Hasegawa T., H. Tanii, M. Suzuki, and S. Tanaka. 2003. Regulation of water absorption in the frog skins by two vasotocin-dependent water-channel aquaporins, AQP-h2 and AQP-h3. Endocrinology 144:4087-4096.

Ip Y.K., P.J. Yeo, A.M. Loong, K.C. Hiong, W.P. Wong, and S.F. Chew. 2005. The interplay of increased urea synthesis and reduced ammonia production in the African lungfish Protopterus aethiopicus during 46 days of aestivation in a mucus cocoon. J Exp Zool 303A:1054-1065.

Janssens P.A. 1964. The metabolism of the aestivating African lungfish. Comp Biochem Physiol 1:105-117.

Janssens P.A. and P.P. Cohen. 1968. Biosynthesis of urea in the estivating African lungfish and Xenopus laevis under conditions of water shortage. Comp Biochem Physiol 24:887898.

Johansen K., J.P. Lomholt, and G.M.O. Maloiy. 1976a. Impor- 
tance of air and water breathing in relation to size of the African lungfish Protopterus ampbibius Peters. J Exp Biol 65: 395-399.

Johansen K., G. Lykkeboe, R.E. Weber, and G.M.O. Maloiy. 1976b. Respiratory properties of blood in awake and estivating lungfish, Protopterus amphibius. Respir Physiol 27: 335-345.

Jørgensen C.B. 1997. Urea and amphibian water economy. Comp Biochem Physiol A 117:161-170.

Kirschner L.B. 1991. Water and ions. Pp. 13-107 in C. Ladd Prosser, ed. Comparative Animal Physiology: Environmental and Metabolic Animal Physiology. 4th ed. Wiley-Liss, New York.

Kitzan S.M. and P.R. Sweeney. 1968. A light and electron microscope study of the structure of Protopterus annectens epidermis. I. Mucus production. Can J Zool 46:767-779.

Koefoed-Johnsen V. and H.H. Ussing. 1958. The nature of the frog skin potential. Acta Physiol Scand 42:298-308.

Laurent P., R.G. Delaney, and A.P. Fishman. 1978. The vasculature of the gills in the aquatic and aestivating lungfish (Protopterus aethiopicus). J Morphol 56:173-208.

Lim C.K., W.P. Wong, S.M. Lee, S.F. Chew, and Y.K. Ip. 2004. The ammonotelic African lungfish, Protopterus dolloi, increases the rate of urea synthesis and becomes ureotelic after feeding. J Comp Physiol B 74:555-564.

Loong A.M., K.C. Hiong, S.M.L. Lee, W.P. Wong, S.F. Chew, and Y.K. Ip. 2005. Ornithine-urea cycle and urea synthesis in African lungfishes, Protopterus aethiopicus, and Protopterus annectens, exposed to terrestrial conditions for six days. J Exp Zool 303A:354-365.

Maetz J. 1970. Mechanisms of salt and water transfer across membranes in teleosts in relation to the aquatic environment. Mem Soc Endocrinol 18:3-29.

Marshall W.S. 2002. $\mathrm{Na}^{+}, \mathrm{Cl}^{-}, \mathrm{Ca}^{2+}$ and $\mathrm{Zn}^{2+}$ transport by fish gills: retrospective review and prospective synthesis. J Exp Zool 293:264-283.

McMahon B.R. 1970. The relative efficiency of gas exchange across the lungs and gills of an African lungfish Protopterus aeithiopicus. J Exp Biol 52:1-15.

Oduleye S.O. 1977. Unidirectional water and sodium fluxes and respiratory metabolism in the African lung-fish Protopterus annectens. J Comp Physiol 119:127-139.

Perry S.F. 1997. The chloride cell: structure and function in the gills of freshwater fishes. Annu Rev Physiol 59:325-347.

Perry S.F., K.M. Gilmour, E.R. Swenson, B. Vulesevic, S.F. Chew, and Y.K. Ip. 2005. An investigation of the role of carbonic anhydrase in aquatic and aerial gas transfer in the African lungfish Protopterus dolloi. J Exp Biol 208:3805-3815.

Potts W.T.W. and W.R. Fleming. 1970. The effects of prolactin and divalent ions on the permeability of water of Fundulus kansae. J Exp Biol 53:317-327.
Potts W.T.W., M.A. Foster, P.P. Rudy, and G. Parry Howells. 1967. Sodium and water balance in the cichlid teleosts, Tilapia mossambica. J Exp Biol 47:461-470.

Potts W.T.W., M.A. Foster, and J.W. Stather. 1970. Salt and water balance in salmon smolts. J Exp Biol 52:553-564.

Rahmatullah M. and T.R.C. Boyde. 1980. Improvements in the determination of urea using diacetyl monoxime; methods with and without deproteinization. Clin Chim Acta 107:39.

Smith H.W. 1930. Metabolism of the lung-fish, Protopterus aethiopicus. J Biol Chem 88:97-130.

Smith H.W. 1931. Observations of the African lung-fish, Protopterus aethiopicus, and on evolution from water to land environments. Ecology 12:164-181.

Stewart P.A. 1983. Modern quantitative acid-base chemistry. Can J Physiol Pharmacol 61:1444-1461.

Sturla M., M.A. Masini, P. Prato, C. Grattarola, and B. Uva. 2001. Mitochondria rich cells in gills and skin of an African lungfish Protopterus annectens. Cell Tissue Res 303:351-358.

Sturla M., P. Paola, G. Carlo, M.M. Angela, and U.B. Maria. 2002. Effects of induced aestivation in Protopterus annectens: a histomorphological study. J Exp Zool 292:26-31.

Toledo R.C. and C. Jared. 1993. Cutaneous adaptations to water balance in amphibians. Comp Biochem Physiol A 105:593608.

Weckell J.C. and H. Barnett. 1991. New method for analysis of trimethylamine oxide using ferrous sulfate and EDTA. J Food Sci 56:132-138.

Wilkie M.P., J. Couturier, and B.L. Tufts. 1998. Mechanisms of acid-base regulation in migrant sea lampreys (Petromyzon marinus) following exhaustive exercise. J Exp Biol 201:14731481.

Wilkie M.P., Y. Wang, P.J. Walsh, and J.H. Youson. 1999. Nitrogenous waste excretion by the larvae of a phylogenetically ancient vertebrate: the sea lamprey (Petromyzon marinus). Can J Zool 77:707-715.

Wood C.M. 1988. Acid-base and ionic exchanges at the gills and kidney after exhaustive exercise in the rainbow trout. J Exp Biol 136:461-481.

Wood C.M., P.J. Walsh, S.F. Chew, and Y.K. Ip. 2005. Greatly elevated urea excretion after air exposure appears to be carrier mediated in the slender lungfish (Protopterus dolloi). Physiol Biochem Zool 78:893-907.

Yancey P.H. 2001. Nitrogen compounds as osmolytes. Pp. 309341 in P.A. Wright and P. Anderson, eds. Fish Physiology. Vol. 20. Nitrogen Excretion. Academic Press, New York.

Zall D.M., M.D. Fisher, and Q.M. Garner. 1956. Photometric determination of chlorides in water. Anal Chem 28:16651678. 